\title{
OS FANALES DEL NIÑO JESÚS Y LA CONSTRUCCIÓN SIMBÓLICA DE LA VIRTUD FEMENINA EN LOS MONASTERIOS DE CÓRDOBA DEL TUCUMÁN (FINES S. XVIII- COMIENZOS S. XIX)
}

VANINA SCOCCHERA

Centro de Investigación en Arte, Materia y Cultura. Universidad Nacional de Tres de Febrero - CONICET vanina.scocchera@gmail.com

\begin{abstract}
Resumen: El presente trabajo se propone desarrollar un estudio de los fanales del Niño Jesús existentes en colecciones de la ciudad de Córdoba (Argentina) cuya procedencia de monasterios femeninos ha sido ampliamente documentada. No obstante, nuestra disciplina carece de investigaciones que aborden el estudio de estos objetos desde una perspectiva que responda a sus procesos de elaboración, seguidos de sucesivas manipulaciones, apropiaciones y resignificaciones simbólicas y materiales que atravesaron a lo largo de su vida. Para responder a estos interrogantes, el presente trabajo se propone iniciar un estudio cultural de la vida cotidiana desplegada en dichos monasterios femeninos para comprender las prácticas de creación de dichos objetos, a la vez que, propone desarrollar un análisis iconográfico y material de sus elementos que nos permita comprender sus sentidos simbólicos, usos y funciones. En este sentido, el presente trabajo abordará los imaginarios construidos en torno de la virtud femenina como una meta a la que las monjas debían aspirar en un camino de perfección y dónde las prácticas contemplativas se entroncaron con las activas y, entre otros, dieron por resultante la elaboración de fanales del Niño Jesús dotados de sentidos polisémicos y eficaces para recordar el destino asumido por estas monjas como mujeres virtuosas y sacrificiales.
\end{abstract}

Palabras clave: Fanales del Niño Jesús / monasterios femeninos / virtud femenina / Córdoba del Tucumán / fines siglo XVIII inicios siglo XIX.

\section{THE CHILD JESUS BELL JARS AND THE SYMBOLIC CONSTRUCTION OF FEMALE VIRTUE IN THE MONASTERIES OF CÓRDOBA DEL TUCUMÁN (LATE 18TH-EARLY 19TH CENTURY)}

Abstract: This paper aims to develop a study of the Jesus Child bell jars existing at repositories of the city of Córdoba, Argentina, whose origin from female monasteries has been widely documented. However, our discipline lacks research that addresses the study of these devotional objects from a perspective that responds to the successive manipulations, appropriations, and symbolic and material resignifications. In order to answer these questions, the present work intends to initiate a cultural study of the daily life cloisters linked to the practices of elaboration of Jesus Child bell jars. At the same time, it proposes to develop an iconographic and material analysis of its elements that allows us to understand their symbolic senses, uses and functions. In this work, we will approach the imaginaries constructed around the feminine virtue as a nun's goal. In the same way, we will analyze how the contemplative practices were connected with the active ones and they gave, as a result, the elaboration of Jesus Child bell jars. These significant objects had polysemous meanings effective to remember the destiny assumed by these nuns as virtuous and sacrificial women.

Key words: Jesus Child bell jars / femenin cloisters / femenin virtue / Córdoba del Tucumán / late 18th century early 19 th century.

* Fecha de recepción: 15 de abril de 2019 / Fecha de aceptación: 10 de diciembre de 2019. 


\section{Introducción}

Entre las numerosas pinturas y series de lienzos que cubren las paredes de las dos clausuras monásticas fundadas en período colonial en la ciudad de Córdoba existen al menos dos obras que aún hoy recuerdan a las monjas la forma propicia de conciliar la práctica activa con la vida contemplativa. La primera de ellas, consiste en una imagen de la Virgen Niña hilando donde la joven mujer se dispone a hilar con un huso acorde a los modelos de virtud marianos (Fig. 1). A esta misma tradición moralizante del temperamento femenino pertenece la serie que relata la vida de santa Rosa de Lima y en uno de cuyos lienzos se representa a Santa Rosa de Lima bordando (Fig. 2). ${ }^{1}$ Estas y otras imágenes constituían algunos de los modelos que debían ser emulados por las monjas y a través de los cuales se promovían prácticas para que la vida activa se reconciliase con la contemplativa. ${ }^{2}$ Así, al interior de los monasterios, las monjas, al igual que lo hiciera Santa Rosa, utilizaban sus propios trabajos manuales como soporte para ejercitar su oración mental y alejar su mente de pensamientos mundanos.

Lo anterior no solo era promovido por las imágenes edificantes sino que también fue incentivado en lecturas espirituales así como en las reglas y constituciones que las monjas acataban con sus votos de profesión. ${ }^{3}$ Sin ir más lejos, estas ideas ya estuvieron presentes en el imaginario conventual al menos desde el siglo XIII, cuando el franciscano Buenaventura recomendaba a las religiosas exhi- bir su habilidad manual entre los vecinos para garantizar su sustento a emulación de la Virgen. ${ }^{4}$ Lo dicho hasta aquí nos pone frente a una estrecha relación no solo entre texto e imagen para componer una imagen virtuosa sino también entre la vida contemplativa y las prácticas activas, y específicamente las labores manuales, que compusieron con el correr del tiempo un imaginario dotado de cualidades piadosas respecto del temperamento de las monjas en la clausura.

No obstante los monasterios femeninos asiduamente justificaron su existencia mediante una construcción discursiva relacionada con la preservación del carácter moral femenino, en la segunda mitad del siglo XVIII la cotidianeidad de estos espacios religiosos en la ciudad de Córdoba estuvo atravesada por un conjunto heterogéneo de prácticas que los vinculó con la vida mundana y social -tales como el intercambio de objetos devocionales y de bienes de prestigio, la entrega de obsequios y el contacto frecuente con personas del exterior y confesores- que sucesivamente obligó a visitadores, obispos y prelados a intervenir en su regulación. ${ }^{5}$ De este modo, el relato que proponemos iniciar aquí es consecutivo a un período de inestabilidades monásticas que, no sin esfuerzos, el clero cordobés se ocupó de corregir.

El marco contextual en el que se desarrolla nuestro análisis de los fanales del Niño Jesús elaborados al interior de los monasterios cordobeses tuvo por desencadenante un incremento del tiempo dedicado a las tradicionales labores manuales. ${ }^{6} \mathrm{El}$

\footnotetext{
1 Esta pintura sobre tabla, ubicada actualmente en la clausura del Monasterio de San José de Córdoba, guarda una estrecha semejanza con la estampa de Cornelis Galle "La vida activa al servicio de la vida contemplativa representada en la aparición del Niño mientras Rosa Borda". MÚJICA PINILLA, Ramón. 2005, pp. 236.

2 Mújica Pinilla recuerda, a su vez, que la piedad laica contrarreformista concibió las artes manuales, a la usanza medieval, como una forma de liturgia y oración -laborare est orare- que santa Rosa adoptó de modo tal que utilizó sus propios trabajos manuales como soporte para su oración mental. MÚJICA PINILLA, Ramón, 2005, pp. 234-237.

3 Para el caso de la ciudad de Córdoba, tanto las reglas del monasterio dominico de Santa Catalina como el carmelita de San José promovían la labor de manos como una actividad que combatía el ocio e invitaba al perfeccionamiento espiritual de las monjas. La Regla y Constituciones de las monjas de la Orden de Santo Domingo. 1863, pp. 307-308, 419. Regla de la Gloriosa Santa Clara con las Constituciones de las Monjas Capuchinas del Santísimo Sacramento de Roma, reconocidas y reformadas por el Padre General de los Capuchinos, 1904, pp. 161-164.

${ }^{4}$ FIDANZA, Juan de (san Buenaventura). 1893 [s. XIII]. Cfr. NÚÑEZ, Antonio, S.J. 1712, pp. 136-140.

${ }^{5}$ SCOCCHERA, Vanina. 2013-2014, pp. 402-407. COHEN IMACH, Victoria. 2003, pp. 19-32; NIEVA OCAMPO, Guillermo. 2011, pp. 53-91.

${ }^{6}$ En relación con el incremento de horas dedicadas a la labor de manos es preciso señalar cómo en diversas correspondencias las prioras justificaban dicha actividad como parte del trabajo que tenían permitido realizar para su sustento, o bien cómo notificaron al clero secular sobre el incremento de las horas destinadas a dicha labor. Por ejemplo, en 1829 Sor María Aurelia de la Santísima Trinidad, priora del Monasterio de Santa Catalina de Córdoba notició al provisor del incremento en las horas de labor al igual que lo había hecho tiempo atrás su predecesora Sor Anselma Catalina de Cristo entre 1801 y 1813 . Mientras tanto, en el vecino monasterio de San José la abadesa Theresa de Jesús informó al prelado que frente a la imposibilidad de pedir limosnas las monjas se habían volcado a la labor de sus manos. Archivo del Arzobispado de Córdoba (Argentina) (en adelante AAC), Legajo 9, tomo I. Monasterio de Santa Catalina, carta de la priora sor María Aurelia de la Santísima Trinidad al provisor, 27/09/1829 y 28/09/1829; Family Search, Archivos eclesiásticos, Convento de Santa Teresa, 1796-1872, expte. 40, Carta de la Priora Theresa de Jesús. "Acerca de la suspensión de Cofradías" 30/01/1814, f. 182.
} 


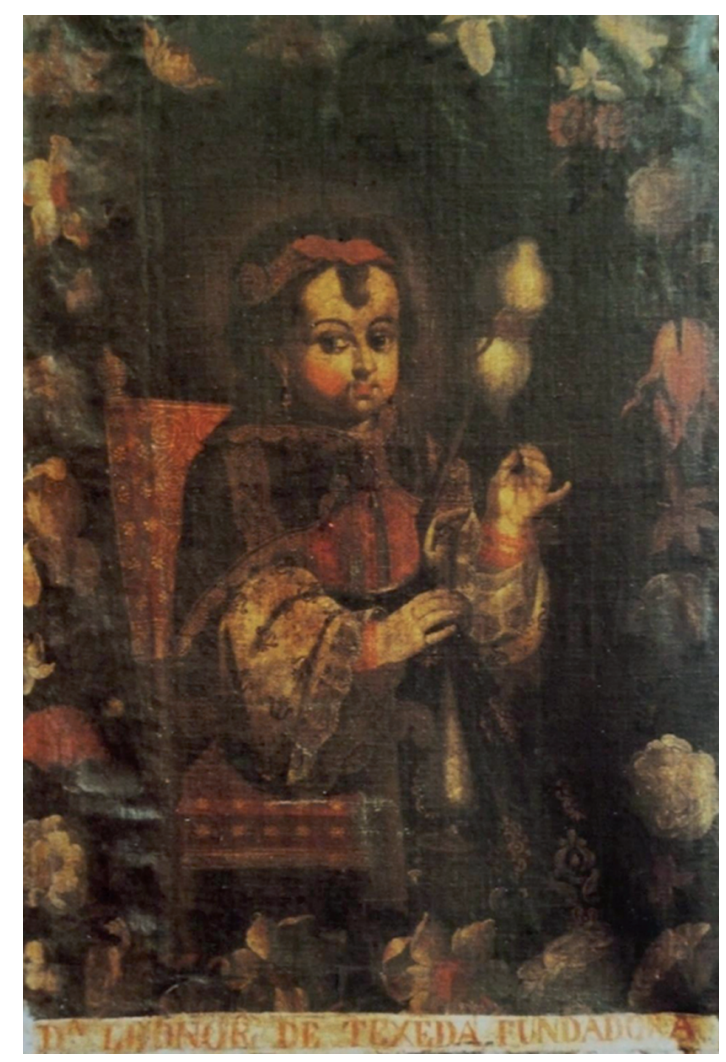

Fig. 1. Virgen Niña hilando, s. XVIII, Cusco. Óleo sobre tela. Monasterio de Santa Catalina, Córdoba, Argentina. Foto: Sergio Barbieri.

énfasis en esta actividad entre fines del siglo XVIII y comienzos del siglo XIX habría formado parte de procesos mayores tendientes a una corrección de la vida en comunidad y del desarrollo de la espiritualidad acorde a los postulados de la ilustración y que hemos desarrollado en otros trabajos. ${ }^{7}$ Si bien existen algunas investigaciones que han reparado en la producción de estos objetos devocionales, no abundan hasta el momento trabajos que indaguen en sus cualidades simbólicas desde una perspectiva que cruce aspectos de la cultura

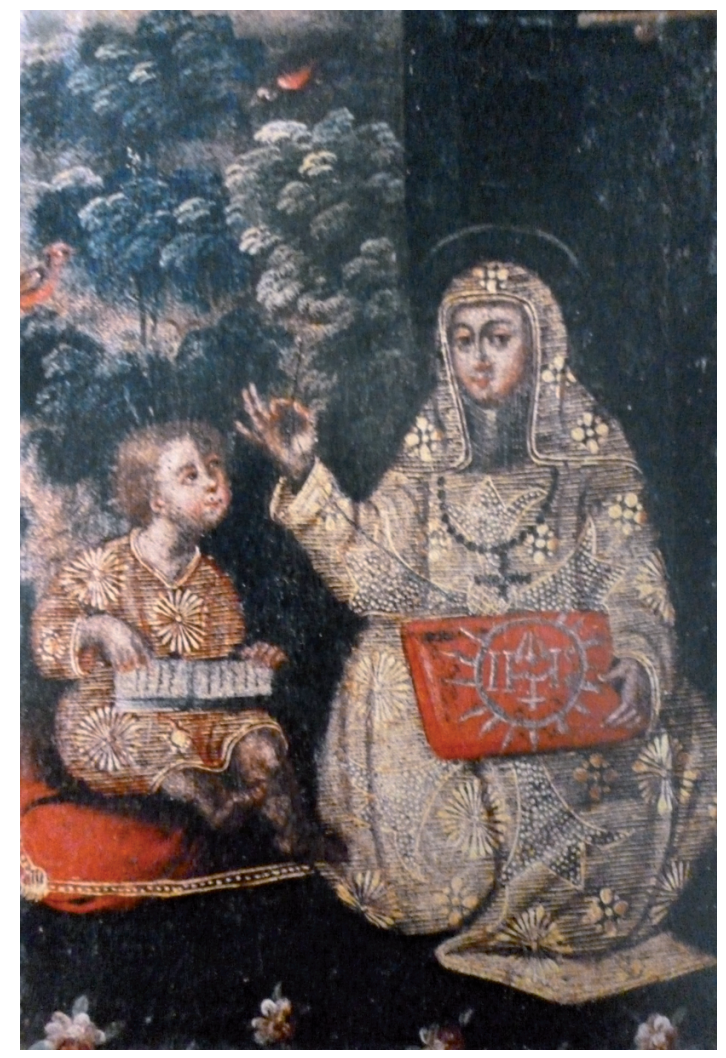

Fig. 2. Santa Rosa bordando, s. XVIII. Óleo sobre tabla. Monasterio de San José, Córdoba, Argentina.

material, la biografía de los objetos junto con un análisis iconográfico para comprender los usos y funciones que estos atravesaron a lo largo de su vida. ${ }^{8}$ En este sentido, consideramos que los fanales del Niño Jesús procedentes de los monasterios femeninos de la ciudad de Córdoba encierran aún numerosas huellas que aguardan ser respondidas.

Sumado a ello, consecuencia de lo perecedero de su materialidad, del carácter artesanal de su producción, y posiblemente de una estética inescindi-

\footnotetext{
${ }^{7}$ Las pretendidas correcciones de la vida en comunidad en los monasterios femeninos puede observarse en los autos de visita donde insistentemente los visitadores, entre los que se encontraban provisores del obispado o los mismos obispos, buscaron evitar el contacto de las monjas con el exterior. AAC, Legajo 9, tomo I y II. Visita a los monasterios de Santa Teresa y Santa Catalina, 1776, 1803, entre otros. Más notable resulta sin embargo cómo en 1823 el visitador del Monasterio de Santa Catalina de Buenos Aires obligó a las monjas a reducir el tiempo destinado a la labor de manos, pues, a pesar de que este reconocía su importancia para garantizar el sustento de las monjas, entendió que su principal actividad debía orientarse a la perfección espiritual mediante la oración y la lectura edificante. Archivo General de la Nación (Argentina) (en adelante AGN) sala X, Culto 4-8-4, 1823. FRASCHINA, Alicia. 2008, pp. 445-466; SCOCCHERA, Vanina. 2019, cap. 3.

8 Algunos de los postulados teóricos que guían la presente investigación son los aportes que desde la historia cultural han realizado DE CERTEAU, Michel. 2006, pp. 33-43 y MARIN, Louis. 2009, pp. 135-153; así como desde la antropología de la imagen y la cultura material resultan puntos de partida ineludibles los trabajos de GELL, Alfred. 2016, pp. 31-41; APPADURAl, Arjun ed. 1986, 17-87; BROWN, Bill. 2001, pp. 1-22.
} 
ble de las prácticas piadosas que les dieron sustento, estos objetos fueron sucesivamente desligados de los relatos de la historiografía virreinal. No obstante, en las últimas décadas han sido numerosas las investigaciones que propusieron una revisión de estas categorías a la vez que pugnaron por una expansión de los límites y los objetos de estudio de la historia del arte. ${ }^{9}$ Por tanto, los objetos devocionales que analizaremos en este trabajo son un testimonio superviviente de prácticas y percepciones pretéritas, cuyas funciones y sentidos polisémicos nos proponemos recomponer a partir de un análisis que cruce los aspectos histórico-culturales de la vida cotidiana en los monasterios femeninos con aquellas dimensiones simbólicas, iconográficas y materiales que resulta factible identificar en dichos objetos.

\section{Labores de mano y la construcción discursiva de los temperamentos virtuosos en la segunda mitad del siglo XVIII}

La importancia de las reglas conventuales radica en que éstas marcaron el ritmo de las actividades diarias y proporcionaban los lineamientos básicos para la observancia religiosa: pautaban los horarios, oficios y oraciones cotidianas, a la vez que establecían las celebraciones del monasterio con el cometido de forjar el carácter espiritual al que las religiosas debían aspirar. ${ }^{10}$ Cada momento del día era previsto y estaba organizado en actividades contemplativas y activas. Las primeras -consistentes en la oración, el canto en el coro, la lectura espiritual y los ejercicios piadosos- tenían por objeto la búsqueda del amor de Dios y la perfección en la vida religiosa; mientras que las segundas se proponían mantener el correcto funcionamiento del monasterio mediante la asignación de oficios y tareas. Sin embargo, y con el objeto de componer una visión edificante del convento, cada práctica era revestida de un sentido trascendente. Momentos mundanos como la comida o las labores manuales eran atravesados por la espiritualidad, ya que el ritmo de estas actividades estaba pautado por el de una lectura edificante. ${ }^{11}$

De todas las tareas diarias desplegadas por las monjas, nos interesa principalmente centrarnos en las labores manuales o las también llamadas de aguja. Sustentadas en una larga tradición, la construcción discursiva en torno a un ideal edificante de esta actividad era recomendada por la Regla de Santa Clara "porque en esto huirán la ociosidad y excusaran parlerías y estarán más libres de tentaciones, y tendrán salud, y cumplirán con lo que la regla manda". ${ }^{12}$ Así, la construcción de un imaginario femenino caracterizado por su castidad y pulcritud encontraba asidero en numerosas referencias literarias y visuales, tales como los relatos de las tareas de la Virgen o las hagiografías de mujeres santas representadas en numerosas series de lienzos y estampas. ${ }^{13}$

Pero ¿de qué modo se desarrollaron estas actividades? En la práctica, la labor de manos estaba reservada a las monjas de velo negro y especialmente a las religiosas que mayor tiempo llevaban en la vida monástica, de modo tal que la realización de dicha tarea componía una jerarquía al interior del claustro. ${ }^{14}$ Según lo que dictaba la regla,

\footnotetext{
9 Desde los ya clásicos trabajos de Riegl y Semper, hasta las revisiones contemporáneas de Warburg y Didi-Huberman estos historiadores del arte han coincidido en señalar las limitaciones de la disciplina respecto de las categorías de análisis de sus objetos de estudio. Asimismo, y especialmente para el arte colonial, propuestas similares en torno al necesario abordaje de las obras de arte en términos contextuales e interdisciplinarios han sido señalados por Schenone y Siracusano, entre otros. RIEGL, Alois. 1992 [1903]; SEMPER, Gottfried. 2004; DIDI-HUBERMAN, Georges. 1996, pp. 145-163; SCHENONE, Héctor. 2014, pp. 91-99, SIRACUSANO, Gabriela. 2005.

${ }^{10}$ Existe numerosa bibliografía que se centra en el estudio de la vida cotidiana en los monasterios femeninos y exhibe el modo en que las reglas monásticas pautaban las actividades allí realizadas por las monjas. Para el virreinato novohispano se pueden consultar los trabajos de LAVRIN, Asunción. 2016, pp. 195-234; MONTERO ALARCÓN, Alma. 2008, entre otros; mientras que para el Río de la Plata resulta de especial importancia el trabajo de FRASCHINA, Alicia. 2010, pp. 159-188.

11 FRASCHINA, Alicia. 2010, p. 165.

12 Regla de la Gloriosa Santa Clara con las Constituciones de las Monjas Capuchinas. 1904, p. 163. Del mismo modo, la Regla de Santo Domingo enfatizó en los inconvenientes de la vida ociosa y por tanto en lo necesario de las labores manuales como parte de las actividades diarias. "Comentarios de la constitución de las RR. MM. Dominicas" en La Regla y Constituciones de las Monjas de la orden de Santo Domingo. 1863, pp. 307-308.

${ }^{13}$ Rodríguez Nóbrega ha señalado cómo la vida cotidiana femenina transcurrió en período colonial entre la observación de imágenes ejemplares para la formación de su carácter. Entre ellas, la autora señala la especial recurrencia de las imágenes marianas así como de santas ejemplares. RODRÍGUEZ NÓBREGA, Janeth. 1999, pp. 371-386.

${ }^{14}$ Así lo indicó el deán Pavón en el auto de visita de 1774. Este auto fue posteriormente suprimido por el obispo Moscoso por considerar que su accionar había sido desmedido en su rigurosidad para con las monjas. En el auto Pavón señaló respecto de las labores manuales "que siempre se procure nombrar para dichos oficios las religiosas más antiguas para que así queden desocupadas las más modernas y puedan ayudar a aquellas en las necesidades para su instrucción y trabajar más en la labor de manos con que socorrer la pobreza del monasterio". Archivo General de Indias (en adelante AGI), Audiencia de Buenos Aires, Legajo 224, Auto de visita del deán Pavón al Monasterio de Santa Teresa, 1774.
} 
fuera de las horas del oficio divino estas monjas se congregaban en una sala de labor para hilar, bordar y tejer al menos en dos momentos del día. ${ }^{15} \mathrm{Al}$ ritmo de las lecturas edificantes, estas tareas incluían desde el arreglo de su hábito hasta la elaboración de prendas litúrgicas, vestimentas para las imágenes de culto y objetos devocionales que las monjas podían utilizar para sí, para su iglesia monástica, o bien obsequiar a sus allegados -como familiares, confesores y visitas especiales- o entregar a ciertos feligreses a cambio de una limosna que garantizara su sustento en casos de especial necesidad. ${ }^{16}$

Consecuentemente, la elaboración de estos objetos estuvo determinada por un entramado virtuoso que tendió a incrementar su valoración simbólica acorde a sus usos vinculados a la exhibición del virtuosismo femenino, la exteriorización del culto o bien, a la práctica piadosa. Basta para ello, por ejemplo, recordar que en este mismo contexto de labores manuales las monjas novohispanas elaboraban las coronas que utilizarían al momento de su profesión religiosa o en los rituales funerarios y de encuentro con el divino esposo. ${ }^{17}$ No obstante hasta el momento no se conocen para el Río de la Plata coronas de monjas, existen sin embargo numerosos objetos devocionales que sí fueron elaborados con análogas características -tales como escapularios, ramos de flores de tela que servirían para rendir culto a las imágenes, decorarían andas procesionales o bien, integrarían los con- juntos de fanales del Niño Jesús-. Asimismo, diversas correspondencias privadas explicitan el valor simbólico asignado a ciertos objetos devocionales que fueron elaborados por monjas y obsequiados a sujetos de distinción como si de un bien de prestigio se tratara. ${ }^{18}$

Más numerosas son las referencias a la recepción de limosnas o de la venta de objetos devocionales elaborados por las monjas e invisibilizados en las fuentes documentales bajo menciones como "labor por costuras", "labor de manos" o sencillamente "sala de labor". ${ }^{19}$ Cabe entonces preguntarnos ¿qué tipo de objetos fueron agrupados bajo estas categorías y fueron percibidos como capaces de condensar las cualidades simbólicas que hemos referido? Una anotación en un inventario de los bienes hallados en la sacristía de la Iglesia Monástica de Santa Catalina de Buenos Aires a mediados del siglo XVIII nos permite ver de manera minuciosa cuáles fueron los diversos objetos realizados en el marco de las labores manuales por una monja:

Lo que hizo la madre Ana María de la Concepción en su tiempo: Primeramente un ornamento de persiana blanca para el día de la Santa con su capa de coro, casulla, dalmáticas, collares, estolas y manípulos guarnecidos todo con sevillaneta de oro... otras dos capas de oro de damasco blanco... el ornamento de persiana blanca arriba dicho tiene su frontal de la misma... cuatro casullas de persiana blanca... todas con sus estolas y manípulos. ${ }^{20}$

15 La Regla y Constituciones, 1863, p. 74-75; Regla de la Gloriosa Santa Clara, 1904, pp. 105-108.

${ }^{16}$ En los libros de cuentas de los Monasterios de Santa Catalina de Córdoba y Buenos Aires puede observarse una frecuente inscripción respecto del ingreso de dinero, como pago o limosna, a cambio de la entrega de labores de mano, entre los que se cuentan los objetos devocionales o las prendas para vestir imágenes elaboradas por las monjas. AAC, Leg. 9. Monasterio de Santa Catalina, 1803, 1817, 1823, entre otros. SCOCCHERA, Vanina, 2013-2014, pp. 402-404.

17 MONTERO ALARCÓN, Alma, 2008, p. 189.

18 Al respecto es preciso señalar que tanto las monjas catalinas como las carmelitas frecuentemente obsequiaban ramos de flores o estandartes florales que fueran útiles para decorar imágenes de culto. Así, las monjas del Monasterio de Santa Catalina obsequiaron a los padres franciscanos ramos de flores para decorar las andas junto con prendas para vestir santos a fines del siglo XVIII y que guardaron en su clausura, a la vez que entregaron a las monjas carmelitas cuatro estandartes florales para decorar el tránsito de la Virgen. AAC, Legajo 9, Autos de visita al Monasterio de Santa Catalina, 1776; y AAC, Monasterio de Santa Catalina, Microfilm, rollo 6, caja 8 Documentación histórica: Estados de cuentas de síndicos 1759-1869, expte. 2, 1798, ff. 5489 a 5507. Más interesante aún resulta que las mismas monjas manifestaron haber obsequiado ramos florales a diversos sujetos de primera distinción política y por el cual, uno de ellos le valió a la priora la acusación de "antipatriótica". El acontecimiento tuvo lugar en 1813 cuando la priora del Monasterio de Santa Catalina de Córdoba fue acusada por el segundo triunvirato de Buenos Aires de "antipatriótica" por lo inoportuno del regalo de un ramo de flores elaborado en el convento al coronel realista don Pedro Barreda -uno de los prisioneros capturados en la batalla de Tucumán en el marco del proceso independentista-. En su defensa la priora María Antonia de Jesús atestiguó que dichos obsequios habían sido realizados con asiduidad a diversos sujetos entre los que se contaba el "Señor Coronel Ocampo, cuando vino de general; con el gobernador Pueyrredón y su hermano, cuando estuvo de presidente de la Junta; con el señor Saavedra y más acompañados, cuando pasó por esta, y con varios otros". AGN, sala X, 4- 7- 2 .

${ }_{19}$ AAC, Leg. 9. Tomo 2. Monasterio de Santa Catalina, 1816, 1822 y MICROFILM, Monasterio de Santa Catalina, Rollo 1, documentación histórica, libros de cuentas 1825-1831, entre otros.

20 Archivo Monasterio de Santa Catalina de Siena, Buenos Aires (En adelante AMSCS), "Memoria y razón de los ornamentos y losa que pertenecen a la sacristía y tiene recibido de orden del II. ${ }^{\text {mo }} \mathrm{Sr} \mathrm{D} .^{\mathrm{n}}$ Fray Joseph de Peralta Obispo de esta Diócesis que entregó a la Madre Ana de la Concepción y que fueron los mismos que dejó nuestro fundador D. ${ }^{n}$ Dionisio Torres Briceño en $1745 ", 1750$. 
El extracto anterior resulta un documento particularmente valioso en tanto contiene información sobre la procedencia de una serie de objetos, su posterior ubicación y uso para el culto de la iglesia monástica, así como la identidad de su creadora. ${ }^{21}$ Esta breve mención exhibe cómo esta monja fue capaz de componer una heterogeneidad de prendas litúrgicas de importante calidad: textiles propios del oficio religioso que incluyeron la vestimenta litúrgica y los ornamentos textiles que sirvieron para propiciar el culto y para vestir imágenes de su iglesia monástica. Frente a la habitual y casi exclusiva mención en fuentes documentales de estas obras con referencias que no son pormenorizados, este documento brinda información muy precisa respecto de cuáles y cuántos eran los objetos elaborados por una monja a lo largo de su vida. Así, pareciera que con el asiento del listado de todas las labores realizadas por la monja se habrían homologado dos biografías, la de una mujer virtuosa y la de un universo de prendas litúrgicas destinadas a promover el culto monástico pero, asimismo, a recordar el carácter ejemplar de la conversa entre sus pares.

En las próximas páginas nos proponemos iniciar un recorrido por el cual podamos develar los modos en que una devoción de especial afecto al interior de la clausura, como lo fueron las imágenes del Niño Jesús, se entroncaron con esta práctica cotidiana monástica tendiente a la construcción de la virtud femenina.

\section{Evocar la virtud femenina. Los fanales del Niño Jesús}

Como numerosas veces ha sido señalado por la historiografía del arte, las imágenes de bulto del Ni- ño Jesús gozaron de una habitual y extendida presencia en las clausuras hispanoamericanas. ${ }^{22}$ Estas esculturas adquirieron un sentido especial en la medida en que resultaron eficaces para activar un momento trascendente en la historia cristiana: la encarnación de Jesús representada en su natalicio. En los conventos femeninos existen, a grandes rasgos, dos tipos de conjuntos en los que las pequeñas imágenes del Niño Jesús eran dispuestas: por un lado, los nacimientos o belenes donde el Niño es dispuesto junto a la presencia de la Virgen y de san José entre muchos otros personajes que completan la composición y, por el otro, los fanales donde la imagen del infante se encuentra aislada y en compañía de una heterogeneidad de elementos que refuerzan su sentido simbólico. Dentro de estos últimos existe asimismo, una clasificación que nos permitirá diferenciar a dichos fanales en dos tipos: Por un lado, aquellos que presentan al niño recostado, en posición de reposo a pesar de que mantiene, en la mayoría de los casos, una mirada activa hacia el espectador o hacia algún punto superior del fanal (Fig. 3). Por el otro, aquellos fanales que presentan al niño como una prefiguración de la vida de Cristo: de pie, como Cristo resucitado, o sentado sobre un trono en clara alusión a un Cristo rey (Fig. 4).

Como ha afirmado Schenone, las imágenes que representan al niño exento tuvieron especial desarrollo en España a partir del siglo XV y en las colonias americanas entre los siglos XVII y XVIII con un especial énfasis en la procedencia quiteña, cusqueña, así como españolas e italianas. ${ }^{23}$ Con el correr de los siglos XVII y XVIII en Hispanoamérica los reposos exentos del Niño Jesús fueron ubicados

21 En consonancia, Barbieri explica para el Monasterio de Santa Catalina de Córdoba que las monjas se especializaron en la confección de vestimentas para las imágenes de los santos, palias, entre otros. Estos objetos compartieron la técnica del bordado con hilos de oro y plata junto a apliques de pedrería, pasamanería y lentejuelas. Asimismo destaca el autor la variedad de puntos de bordado existentes en dichas obras como testimonio de la habilidad de sus manufactureras. BARBIERI, Sergio. 2006, pp. 26-27.

22 Desde la perspectiva de la historia del arte, constituyen antecedentes ineludibles respecto de la catalogación de fanales procedentes de espacios monásticos de nuestra región los trabajos de Báez para la colección del Monasterio de la Merced de Santiago de Chile y el ya mencionado estudio sobre relevamiento patrimonial del Monasterio de Santa Catalina de Córdoba realizado por Barbieri. Por su parte, los trabajos de Schenke y Sanfuentes abordan la intrínseca relación existente entre estos fanales del Niño Jesús y las devociones desplegadas al interior de los monasterios femeninos chilenos en torno de las novenas del aguinaldo. Estos trabajos comparten con nuestra perspectiva el interés por el estudio de los aspectos iconográficos junto a las prácticas en las que estos objetos se inscribieron. BÁEZ, Rolando; VARGAS, Emilio. 2015; BARBIERI, Sergio. 2006; SCHENKE, Josefina. 2010, pp. 137-172; SANFUENTES, Olaya. 2011, pp. 161-180.

23 La devoción al Niño Jesús tuvo su principal representación plástica con el empleo de pesebres, fomentados por la orden franciscana como consecuencia de la visión milagrosa que tuvo Juan de Greccio, un caballero italiano, sobre la recuperación de un niño exangüe a manos de san Francisco. Este acontecimiento fue interpretado por la orden como una manifestación del deseo de Cristo de ser adorado mediante efigies simbólicas. Posteriormente, esta tradición llegó a Nápoles donde se adoptó con fervor, dando origen a una gran producción de imaginería. Si bien Schenone ha señalado a Carlos III y su esposa como los responsables de la inclusión de la tradición de los belenes en España en el siglo XVIII, escritos recientes han señalado la presencia de belenes en España ya en el siglo XVI en algunos monasterios femeninos, tales como el Convento de San José de Toledo o el Convento de Santo Domingo de Écija y Sevilla así como también dichos nacimientos estuvieron presentes en los 


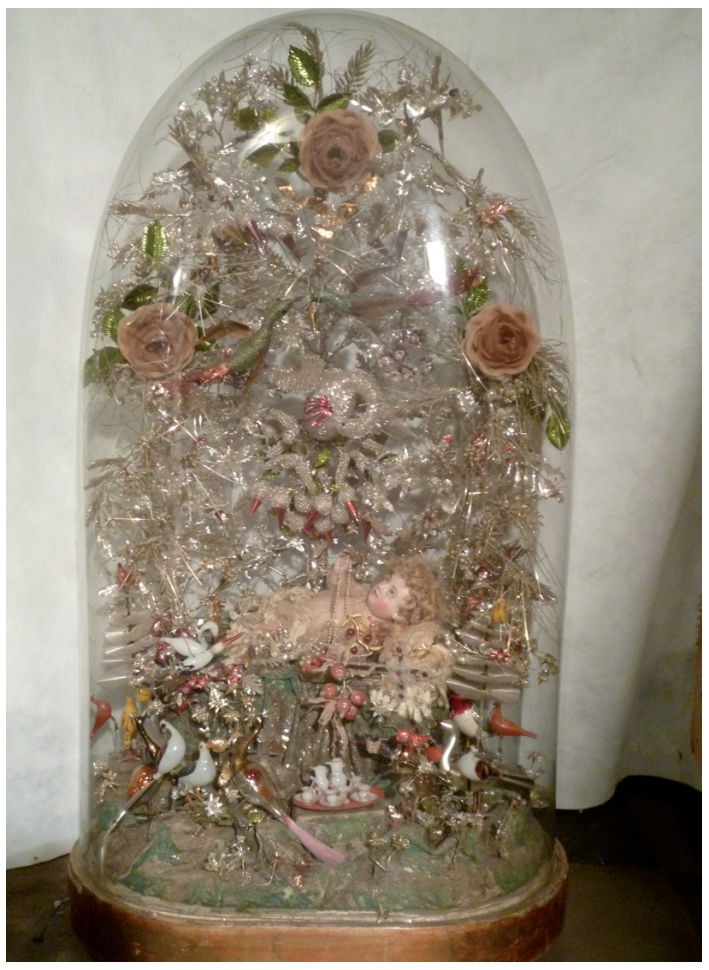

Fig. 3. Fanal del Niño Jesús, s. XIX. Museo de Arte Religioso Juan de Tejeda, Córdoba, Argentina.

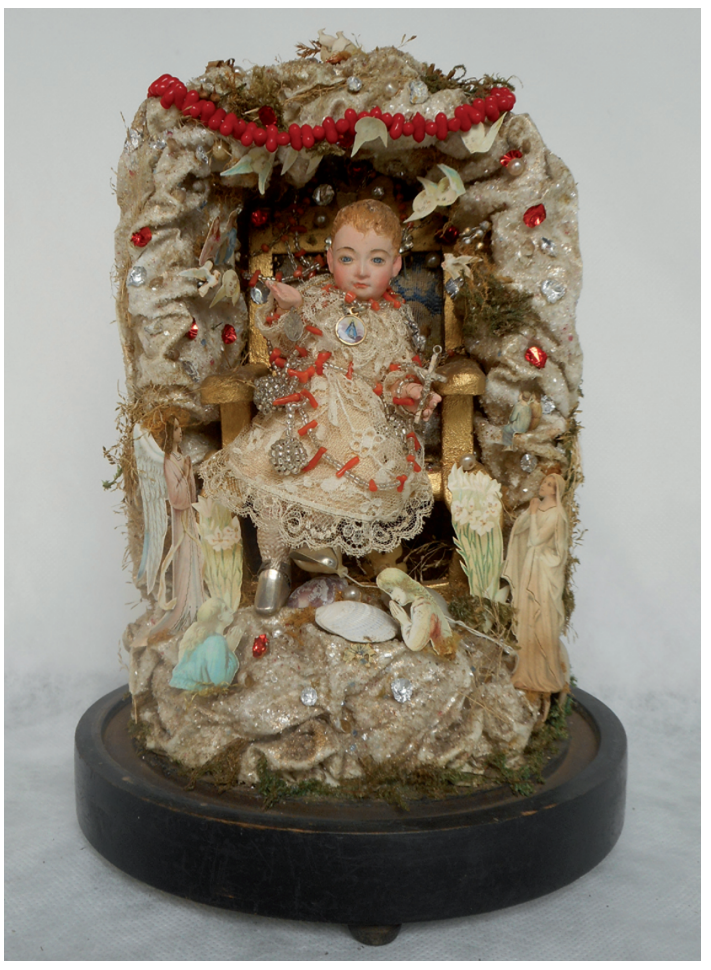

Fig. 4. Fanal "El peruanito", s. XIX. Museo de Arte Religioso Juan de Tejeda, Córdoba, Argentina. en nichos de vidrio donde pudieran ser preservados. A comienzos del siglo XIX, con la posterior introducción de las cúpulas de cristal francesas -que eran empleadas para preservar los ramos de novias-, las pequeñas esculturas del Niño Jesús fueron dispuestas en complejos fanales donde eran ornadas por una diversidad de pequeños elementos.

Estos fanales comparten el hecho de estar compuestos por pequeñas esculturas realizadas en madera, cera o porcelana policromada con encarnes, ojos de vidrio o policromados y pelucas de pelo natural. Generalmente los niños son presentados vestidos y recostados sobre camas de plata o grutas que recuerdan su nacimiento; aunque puede haberlos en diversas posturas, de pie o sedentes. Fue entonces desde los inicios del siglo XIX que fanales de vidrio y esculturas del Niño Jesús se conjugaron hasta crear abigarradas composiciones donde estas imágenes fueron ataviadas por numerosas flores elaboradas por las monjas en diversos materiales.

Entre los objetos dispuestos en el fanal debemos distinguir al menos tres tipos: aquellos manufacturados y de bajo costo -frutas, animales, pequeños figurines, estampas, entre otros-, otros elaborados por sus poseedoras en el contexto de labores manuales -flores, animales, u objetos devocionales-, y aquellos bienes de prestigio -especialmente joyas o alhajas- que, como extensión de algo propio, fueron ofrecidos para formar parte de estas imágenes. ${ }^{24}$ En estos conjuntos, la escultura del

espacios domésticos de la nobleza. Dentro de la imaginería exenta del Niño Jesús existen diversas tipologías que prefiguran aspectos de su vida o bien, muestran un costado más cotidiano y humanizado. En el primer grupo se engloban tipologías como el Niño Rey, Pasionario, Nazareno, Triunfante, etc.; mientras que en la segunda se lo representa recostado destacando su humanidad. Estos últimos niños, con la variante de encontrarse despiertos o dormidos, se ubican en pequeñas camas o cunas originando los denominados reposos de Jesús. SCHENONE, Héctor. 1951, pp. 32-37; 1998, pp. 47 y ss. Cfr. ARBETETA MIRA, Letizia, 2002; GARCÍA SANZ, Ana, 2010 y RAMOS SOSA, Rafael (dir. y coord.), 2010.

${ }_{24}$ Podemos identificar entre ellos algunos objetos que, por sus materiales, habrían sido más preciados como joyas de oro y plata (anillos, crucifijos, cadenitas) o bien estampas, estatuillas de vidrio o porcelana. Mientras que entre aquellos que pueden haber sido elaborados por sus dueñas abundan las flores de tela o mostacillas realizadas mediante técnicas de bordado y pasamanería, objetos que proceden del mundo de las labores manuales. 
niño es acompañada por objetos compuestos de los más diversos materiales -tela, piedras preciosas y artificiales, cerámica, papel, cuentas de vidrio, espejos, etc.- entre los que destaca la insistencia en motivos florales comprimidos por la cúpula de cristal.

Si bien la historiografía del arte sudamericana ha señalado recurrentemente que estas obras tuvieron por principal función su empleo en prácticas piadosas durante la celebración de la natividad cuando eran auxiliadas por lecturas de novenas del aguinaldo, ${ }^{25}$ el análisis visual y material que a continuación presentaremos sobre dieciséis fanales del Niño Jesús procedentes de colecciones cordobesas -museos, colecciones particulares y clausuras monásticas- nos permitirá considerar la presencia de otros posibles usos desarrollados por las monjas que exceden exclusivamente a las prácticas ceñidas a las celebraciones del natalicio de Cristo. Lejos de tratarse de una simple superposición azarosa de elementos, consideramos que estos pequeños objetos revisten un mensaje muy concreto. Nuestra investigación nos permitió identificar que la repetición de ciertos ele- mentos significantes dispuestos en el interior de los fanales habría tenido por objeto referir al menos a dos temáticas de especial relevancia para el contexto monástico: la prefiguración de la pasión de Cristo por el Niño Jesús y el desposorio místico entre la monja y Cristo. En este sentido nuestra hipótesis postula que dichas imágenes podrían haber sido efectivas, y por tanto utilizadas, no solo en el marco de las celebraciones de la Navidad sino también en el ciclo de la Pasión y en un vínculo cotidiano entre la monja y la imagen frente a la cual esta refrendaba sus votos de profesión. ${ }^{26}$

En las páginas siguientes proponemos sumergirnos en un análisis que entrecruce ciertos aspectos de la vida cotidiana monástica con aquellos indicios que la materialidad y la iconografía de los fanales del Niño Jesús para comprender de qué modo las monjas fueron capaces de componer una imagen eficaz y polisémica que diera cuenta de sus vínculos con esta devoción y de su percepción como mujeres virtuosas en los monasterios femeninos de Santa Catalina y San José de Córdoba entre fines del siglo XVIII y comienzos del siglo XIX. ${ }^{27}$

25 Las novenas del aguinaldo consistían en rezos que se realizaban frente a la imagen del Niño Jesús los nueve días previos a la conmemoración de su nacimiento. Estos rezos tienen por objeto exaltar el misterio de la Encarnación de Cristo y su carácter salvífico de la humanidad. Las novenas de esta devoción, y de muchas otras, fueron impresas como pequeñas lecturas espirituales que el grupo familiar leía congregado frente a la imagen, práctica que no resultaba exclusiva del género femenino. Para nuestra región, Furlong menciona que una novena de este tema titulada Novena al Nacimiento de Nuestro Señor JesuChristo fue editada en 1786 en la Casa de Niños Expósitos de Buenos Aires. FURLONG, Guillermo S.J. 1953. A su vez, esta devoción había sido promovida por las monjas del Monasterio de Santa Catalina mediante la fundación de capellanías a partir de sus rentas personales. Así, en 1742 la madre Gertrudis de Jesús fundó una capellanía por doscientos pesos para misas del aguinaldo, en 1786 sor Inés de Luján instituyó otra capellanía de doscientos cincuenta pesos también en favor de dicha devoción. Por último, en 1797 sor Damiana del Corazón de Jesús destinó cien pesos para una misa cantada en la vigilia de la natividad del Señor. Archivo del Arzobispado de Córdoba (en adelante AAC), Monasterio de Santa Catalina, Microfilm, rollo 6, Documentación histórica 1758-1858, leg. 79 1742, ff. 6155- 6157; AAC, Monasterio de Santa Catalina, Microfilm, rollo 6, Documentación histórica 1758-1858, leg. 79, 1786, f. 6170; AAC, Monasterio de Santa Catalina, Microfilm, rollo 6, Documentación histórica 1758-1858, leg. 83, 1797, f. 6185.

${ }^{26}$ La cita anterior cobra un especial sentido cuando recordamos lo formulado por Héctor Schenone respecto de la elaboración y uso de los fanales del Niño Jesús realizadas por las monjas de los monasterios cordobeses entre fines del siglo XVIII y comienzos del siglo XIX. El historiador del arte explica que en buena medida las imágenes del Niño Jesús, y especialmente los fanales, debieron su ingreso a los claustros como parte de las dotes simbólicas que las monjas ingresaban con motivo de su "matrimonio" con Cristo. SCHENONE, Héctor, 1951, p. 37. Si bien hasta el momento no hemos hallado documentación que confirme esta hipótesis, la extensa presencia de estas obras en contexto monástico, así como la habitual mención a imágenes de niños entre sus inventarios parecerían contribuir a dicha idea. En un sentido más amplio, estas a semejanza de lo que sucediera en otras latitudes americanas donde la imagen del Niño Jesús cumplía un papel determinante en la toma de hábito de las monjas en carácter de Niño Esposo mediante el cual, junto con ramos de flores, palmas y un anillo, se representaba el matrimonio místico con Cristo. Este tema ha sido tratado en diversas publicaciones, incluida su tesis doctoral, por PEÑA MARTíN, Ángel. 2011; 2017.

27 En su investigación Siracusano ha demostrado la relevancia metodológica del estudio de la materialidad como una fuente histórico-cultural en paridad con las obras de arte y las fuentes documentales. SIRACUSANO, Gabriela. 2005, pp. 15-59. Respecto de las colecciones, el Museo de Arte Religioso Juan de Tejeda alberga una colección de fanales procedentes del Monasterio de San José, el Museo San Alberto asimismo posee fanales del antiguo Colegio de Niñas huérfanas y educandas que había sido fundado por el obispo en la ciudad de Córdoba. Asimismo el Museo Nacional Estancia Jesuítica de Alta Gracia y Casa del Virrey Liniers posee un fanal procedente del Monasterio de Santa Catalina de Siena de Córdoba, al igual que estos objetos pueden encontrarse en varias colecciones privadas en territorio nacional e hispanoamericano. Especialmente para el caso novohispano, las coronas floridas -empleadas por las monjas al momento de su profesión y muerte como símbolo de su casamiento místico- exhiben un recurrente empleo de las técnicas de hilado, cosido y bordado con materiales que recuerdan a los casos que aquí analizaremos. 


\section{3.a. La prefiguración de la Pasión de Cristo en los fanales del Niño Jesús}

La recurrente presencia de un grupo heterogéneo de pequeños objetos que acompañan a la imagen del Niño Jesús, y que a simple vista parecieran resultar meros motivos ornamentales, constituyen desde nuestra perspectiva elementos simbólicos tanto desde su iconografía como desde su materialidad-de los antiguos usos y funciones que estos fanales adquirieron en la clausura femenina. Si recordamos los planteos de Omar Calabrese respecto de la pregnancia del detalle en la obra de arte, veremos cómo en nuestro caso, son estos pequeños objetos los que nos permiten recomponer ciertos aspectos significantes y materiales que, de un modo acumulativo, habrían sido capaces de componer un mensaje simbólico en estos fanales que remitió insistentemente a las virtudes de Cristo encarnado y de María. ${ }^{28}$

En primer lugar, y respecto de aquellos elementos que contribuyeran a la prefiguración de la $\mathrm{Pa}$ sión de Cristo, existe entre los fanales del niño recostado una recurrente presencia de elementos que desde su significación icónica recuerdan episodios de la vida de Cristo cargados de sentidos moralizantes. Por ejemplo, la reiterada presencia de candelas, velas y candelabros realizados en vidrio que, a primera vista podría considerarse como meramente ornamental, refiere al tipo iconográfico del misterio de la Encarnación de Cristo, por el cual este habría venido al mundo a redimir los pecados de los hombres. (Fig. 5). ${ }^{29}$ Asimismo, la abundante presencia de cántaros y jarrones de pequeño tamaño serían una alusión a una de las escenas de la infancia de Cristo, vinculadas a su modelo de humildad y bondad (Fig. 6). Schenone ha señalado que este tema recuerda a la escena por la cual la Virgen María, mientras bordaba, se admiró de ver al Niño Jesús llevar cántaros de agua y colaborar con los quehaceres domésti$\cos ^{30}$

Como ya hemos señalado, la iconografía del infante condensó en las imágenes del Niño Jesús la prefiguración de su carácter pasionario y salvífico a través de atributos que aludieran a diversos episodios de su vida. Quizás una de las imágenes más elocuentes sobre su prefiguración está constituida por las pequeñas esculturas que representan al Niño recostado sobre la cruz y que representa sus sueños sobre los sufrimientos de la Pasión. Según Schenone este tema surge en el siglo XVI y fue objeto de especial meditación. ${ }^{31}$ En el caso de los fanales que aquí analizamos, para completar el sentido de esta escena pasionaria se adosó a las esculturas recostadas del Niño Jesús -no siempre durmiente- cruces que reiteradamente fueron realizadas con mostacillas y perlas que, por su técnica, recuerdan a numerosas prendas litúrgicas elaboradas por las monjas en el marco de las labores manuales (Fig. 6).

A causa de la reiterada presencia de las perlas en las cruces que abraza el Niño Jesús, así como en los collares y vestimenta que luce, nos ha parecido oportuno indagar brevemente respecto de los sentidos simbólicos adquiridos por este material. Las perlas constituyen un material de especial prestigio y cuya valoración simbólica se encuentra amparada en una tradición que se remonta hasta la antigüedad clásica cuando fueron entendidas como una metáfora de un matrimonio entre el cielo y la tierra. Más interesante aún fue la analogía que se estableció desde el medioevo entre su constitución natural y la encarnación de Cristo, tal como parece establecerse en uno de los fanales donde un pequeño Niño Jesús surge de una madre perla (Fig. 6). ${ }^{32}$ Asimismo, según afirma Fricke y en un juego de analogías con el nacimiento de Venus como creación divina, para la primera modernidad las perlas aludieron tanto al carácter vir-

\footnotetext{
28 CALABRESE, Omar. 1999, pp. 84-106.

29 RÉAU, Louis. 2000, pp. 267 y ss. De un total de 16 fanales que conforman nuestro corpus de las colecciones de Córdoba al menos 7 de los fanales tienen velas de cera, candelabros de pie y en forma de araña que exhiben la presencia de pequeñas velas realizadas en cera o vidrio soplado.

30 Según Schenone, se trata de una temática presente en los evangelios apócrifos. Del mismo modo, la presencia de utensilios de cocina, como vasos y platos, podría recordar las escenas pictóricas de La comida de la sagrada Familia, que el autor identifica como un tema bastante difundido en América que tiene por objeto destacar la humildad de la familia de Cristo (Fig. 3). En esta escena José, María y el Niño son representados sentados a la mesa servida con alimentos pobres y en poca cantidad por el cual "no se alimentan menos en el alma que en el cuerpo". En algunos ejemplos de pintura cusqueña la temática de la obra es completada con la actitud del niño que bendice la mesa, mientras que sus padres -como si fueran religiosos en el refectorio- lo acompañan en la oración. SCHENONE, Héctor. 1998, pp. 93-96.

31 SCHENONE, Héctor. 1998, pp. 113-114.

32 Para Clemente de Alejandría, doctor de la Iglesia en el siglo II, las perlas eran una imagen de la encarnación que aludieron al topos del logos luminoso. Las perlas eran el fruto perfecto de la conjunción entre el cielo y la tierra y por tanto frecuentemente la imagen de María fue asimilada a la de Venus. FRICKE, Beata. 2012, pp. 35-53.
} 


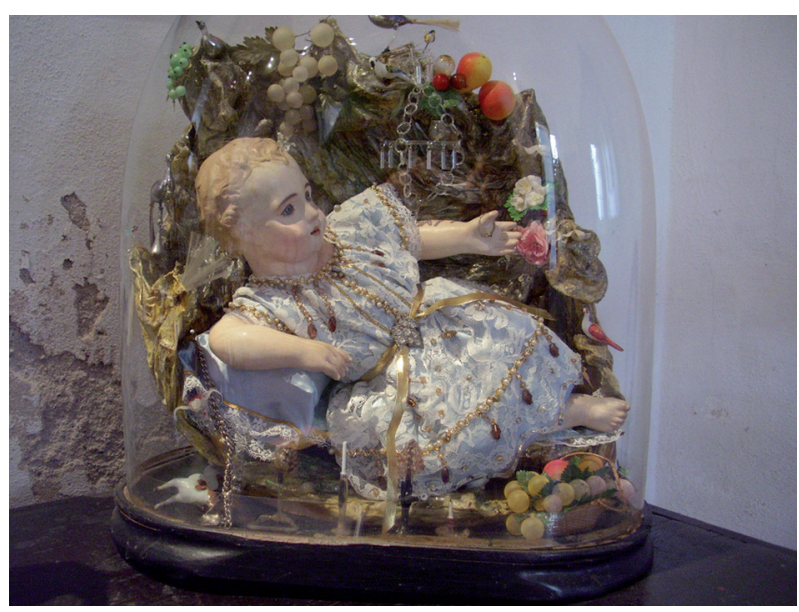

Fig. 5. Fanal del Niño Jesús, s. XIX. Museo de Arte Religioso Fray José Antonio de San Alberto, Córdoba, Argentina.

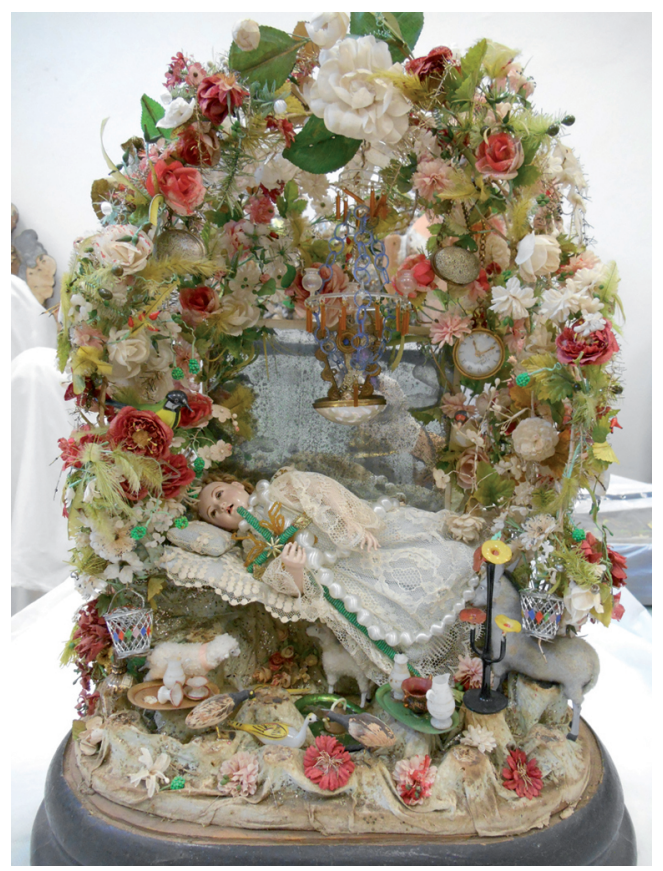

Fig. 6. Fanal del Niño Jesús, s. XIX. Museo de Arte Religioso Juan de Tejeda, Córdoba, Argentina. ginal de María como a la pureza de su concepción. Así, esta exégesis tuvo por objeto promover una contemplación activa por el cual un elemento de la naturaleza, como una perla o una madre perla, revelase un significado escondido y por tanto fuera un objeto propicio para ornar las imágenes sagradas. ${ }^{33}$ En nuestro caso, la recurrente presencia de corales, perlas y madre perlas serían una directa alusión a la encarnación de Cristo y al carácter virginal de María que hunden sus raíces en una extendida tradición atenta a la construcción simbólica en torno de su materialidad (Figs. 4 y 6). ${ }^{34}$

En continuidad con el relato que anticipa el destino salvífico de Cristo, uno de estos fanales exhibe una borla de flores con dos canastas de plata actualmente vacías (Fig. 6). El origen iconográfico de estas canastillas remite al ciclo de la Pasión cuando los soldados romanos guardaron en canastos aquellas herramientas necesarias para llevar a cabo la crucifixión y que según Schenone tuvo su primera representación en la estampa de Van Sichem a mediados del siglo XVI. ${ }^{35}$ Hemos identificado asimismo la presencia de dichas canastillas con sus elementos -la pinza, la esponja, los clavos, etc.- en fanales andaluces y por lo cual es factible suponer que los conjuntos cordobeses hubieran tenido dichos elementos, posteriormente perdidos. ${ }^{36}$ Habría sido entonces tiempo después que, producto de un proceso de apropiación y resignificación, dichas canastillas fueron policromadas con esmaltes modernos para dotar al conjunto de una nueva decoración.

Asimismo, entre la colección de fanales existentes en estas colecciones se encuentran otras imágenes que refieren al carácter sacrificial y triunfal de Cristo por fuera del ciclo de la Pasión. Entre ellos, y particularmente interesante por su laboriosa factura manual, resulta el fanal del Niño Jesús que eleva sus ojos hacia la contemplación de un pelícano que pareciera lastimarse a sí mismo para alimentar a sus crías (Fig. 3). Las aves que dominan la

33 Tal es así que, por ejemplo, entre los bienes donados por la feligresía novohispana a la Virgen de los Remedios se enlistan una cantidad de rosarios de perlas, así como las mismas perlas o aljófares se utilizaron para ornar los vestidos de la Virgen. FLORENCIA, Francisco de. 1685, pp. 22-24, 48 y ss.

${ }^{34} \mathrm{Al}$ respecto pueden consultarse los escritos de Lope de Vega en los que usa recurrentemente las analogías entre la belleza femenina y la de las perlas. Asimismo, en algunos de sus versos Lope establece una analogía entre las perlas y las lágrimas. Esta relación tendría su origen en la cultura árabe donde las perlas representaban las lágrimas de Adán y Eva tras la muerte de su hijo Abel. VEGA CARPIO, D. Frey Lope Félix de. "La Circe" Canto 1, 1776, pp. 3-25. FRICKE, Beata. 2012, pp. 35-47.

${ }^{35}$ La lámina mencionada por el investigador representa el tema de las Dos Trinidades realizada por Cristóbal van Sichem. En esta estampa el niño carga la cruz y lleva una canasta con tenazas, clavos, martillo, etc. La misma canasta puede encontrase asimismo en los lienzos Jesús cargando la cruz y Cristo es clavado en la cruz que forman parte del ciclo de la Pasión de la iglesia del Pilar de Lima. SCHENONE, 1998, p. 103.

${ }^{36}$ Solo por mencionar un ejemplo de los muchos Nazarenos presentes en las clausuras españolas, existe un fanal del Niño Jesús en el Museo del Monasterio de Santa Paula de Sevilla que exhibe a un Niño Jesús de pie que porta en su mano izquierda una canastilla con los instrumentos de la Pasión a la vez que eleva su mirada sufriente al cielo. 
composición de este fanal, y que refieren al sacrificio de Cristo por los hombres como prueba de su altruismo, están íntegramente realizadas con hilos de plata bordados. Asimismo, el Monasterio de Santa Catalina preserva entre su colección un fanal dedicado íntegramente a este tema en el cual las imágenes de dichos animales fueron realizadas con perlas, mostacillas y espejos. ${ }^{37}$ Estas obras constituyen una notable manifestación de las habilidades creativas y técnicas alcanzadas por las monjas en el siglo XIX. En ellas, no solo destaca su habilidad en el empleo de la aguja sino también un saber técnico que se extiende al empleo de una multiplicidad de elementos vinculados al gusto barroco -espejos, papel oropel, mostacillas- y a la elaboración de vestimentas litúrgicas -hilos de oro y plata- que son conjugados en estas imágenes.

Este gusto por componer imágenes a partir de una materialidad heterogénea encuentra su asidero en una forma de experimentar la devoción vinculada a la tradición barroca que tuvo por objeto exaltar los sentidos perceptivos para evocar un mensaje divino. En este caso, la elaboración de objetos devocionales con una clara meta moralizante fue una forma por la cual las monjas pudieron conciliar la vida activa con la contemplativa. Así, los fanales compuestos en el marco de las labores manuales habrían tenido por objeto no sólo ser una representación de la virtud de Cristo sino más bien una exhibición de la conjugación de los saberes manuales y del perfeccionamiento espiritual al que aspiraron las monjas con su práctica cotidiana.

De este modo, la multiplicidad de pequeños objetos que componen los fanales del Niño Jesús, lejos de ser una manifestación popular -entendida como parte de una cultura alejada de los saberes hegemónicos de una época- o un arte menor -acorde a la carencia de prestigio de sus materiales o de referencias estilísticas que los enlace con una tradición académica-, son elementos capaces de condensar huellas de tiempos pretéritos y contemporáneos que se superpusieron como diversas capas de sentido con la finalidad de componer una imagen edificante en torno del carácter sacrificial de Cristo. Si, como ya se ha dicho, el siglo XIX estuvo caracterizado por una superposición entre dos modos de percibir la religiosidad -barroco e ilustrado, resulta posible considerar estos objetos como nexos articuladores y testimonio de dichas tensiones. ${ }^{38}$

La recurrente caracterización historiográfica de estos objetos como arte popular, encuentra una limitación al menos en dos sentidos: por un lado, si tenemos en cuenta que la principal función de los fanales al Niño Jesús estaba destinada al desarrollo de una piedad íntima y privada en el espacio monástico -en contraposición a la exaltación de la feligresía que despertaban los belenes dispuestos en sus iglesias- es factible suponer que su origen habría sido resultado de una adecuación de la devoción, en un repliegue hacia el interior, a las nuevas pretensiones de la ilustración desarrolladas a lo largo del siglo XIX. ${ }^{39}$ Por el otro y contrariamente a la consideración de la introducción de estos elementos de modo azaroso, los objetos incorporados en los fanales por las monjas constituyen detalles que parecen haber tenido por meta completar las referencias iconográficas cristológicas inscritas en una tradición tridentina ampliamente conocida por las monjas y que se encontraba vigente aún tras la caída del antiguo régimen. ${ }^{40}$

Por último, en esta clasificación iconográfica de fanales vinculados al relato de la vida de Cristo, y especialmente al tema de su triunfo existen fanales

\footnotetext{
37 BARBIERI, Sergio. 2006, p. 136.

38 A lo largo del siglo XIX fueron constantes las tensiones entre las prácticas piadosas barrocas -otrora exteriorizadas en la religiosidad de los fieles en las iglesias, las calles y la plaza- frente a otro tipo de devoción vinculada con los ideales ilustrados y caracterizada por una práctica espiritual más íntima y ascética que se desarrolló puertas para adentro en la individualidad de la habitación, la sala o la celda y en favor de las cuales las primeras fueron lentamente cediendo terreno.

${ }^{39}$ Por tratarse de una devoción desplegada durante el siglo XIX, Sanfuentes la clasifica de popular en clara oposición a los ideales ilustrados. No obstante, la misma autora precisa que la ilustración buscó corregir las manifestaciones sociales de religiosidad que, por ejemplo, se desarrollaron en torno de los grandes nacimientos dispuestos durante el siglo XVIII en iglesias monásticas. SANFUENTES, Olaya. 2011, p. 164. En este sentido, si tenemos en cuenta que los fanales son una creación del siglo XIX que invitó al fiel a recogerse en el interior de su hogar en la contemplación de la imagen activada por el rezo de una novena y su ornamentación, podríamos suponer que el inicio de esta práctica se debió a una pretensión de adecuación con los nuevos ideales de una piedad intimista promovidos por la ilustración. Por lo dicho anteriormente -y si bien este no constituye el tema central de nuestra investigación- consideramos que las expresiones "popular" o "sublimación maternal" son términos que en buena medida invisibilizan las problemáticas inherentes a este tipo de objetos, cuya particularidad debe ser comprendida a la luz de una superposición en los modos de manifestar y de sentir la religiosidad a caballo entre dos siglos. Al respecto, una reflexión teórica de especial importancia para nuestra perspectiva sobre los términos "religiosidad" y "popular" y sus acepciones peyorativas ha sido planteada por FOGELMAN, Patricia. 2012, pp. 5-35.

40 Cfr. SANFUENTES, Olaya. 2011, p. 164; BÁEZ, Rolando; VARGAS, Emilio. 2015, pp. 21-26; FOGELMAN, Patricia. 2012, pp. 7-11.
} 
que representan al Niño Jesús de pie como Salvador del mundo tras su resurrección en actitud bendiciente, ${ }^{41}$ así como los niños sentados sobre un sillón frailero que aluden a su carácter de juez supremo en el fin de los tiempos y que recuperan muchos de los elementos que hemos mencionado previamente (Fig. 4). Para concluir nuestra clasificación es preciso señalar que dentro de esta misma línea temática procede de la clausura del Monasterio de San José un niño recostado que, entre los objetos a sus pies, posee un ostensorio o custodia en miniatura, elemento que simboliza el milagro de la transustanciación y donde se preserva el cuerpo de Cristo tras su venida al mundo, acontecimiento que es celebrado en la fiesta del Corpus Christi.

Todos los pequeños objetos incorporados a los conjuntos de fanales procedentes de los monasterios de Santa Catalina y de San José de Córdoba constituyen pequeños indicios de un pasado latente y conocido por sus creadoras que remite a un único relato: el ciclo de la vida de Cristo, su encarnación, Pasión, así como a su carácter salvífico representado en los fanales que expresan su sacrificio, triunfo y transustanciación. Acorde a los diversos ciclos y temas representados en los fanales del Niño Jesús consideramos que estos objetos no sólo habrían resultado eficaces en tiempos del ciclo navideño, como insistentemente afirmó la historiografía del arte, sino que también su carácter agente podría haber sido desplegado en distintas celebraciones del calendario litúrgico, y más especialmente durante la cuaresma. Así, la incorporación de ciertas miniaturas manufacturadas -como los candelabros, los cántaros, las arañas, las canastitas de plata, la custodia, etc.- junto con otros elementos elaborados al interior del monasterio las cruces de cuentas, los pelícanos, la vestimenta del niño, entre otros habría tenido por objeto componer un mensaje que condensara los aspectos centrales de la humanidad del Salvador, desde su venida al mundo y su infancia hasta el ciclo de La Pasión y su Resurrección.

La multiplicidad de sentidos acumulados y condensados en estos fanales implica que consideremos que su continua transformación mediante la incorporación de nuevos elementos nos invita a adoptar una mirada que contemple su anacronismo. Lo an- terior implica considerar que estos objetos poseen una serie de vivencias y experiencias por la cual sus sentidos y eficacia fueron continuamente actualizados, resignificados y apropiados. Por tanto los fanales aquí analizados no pueden ser concebidos como una obra acabada ni reducidos a un momento preciso y único de la historia ya que no son "ni un simple acontecimiento en el devenir histórico ni un bloque de eternidad insensible a las condiciones de ese devenir". ${ }^{42}$ Es bajo este concepto de anacronismo que consideramos, como ya ha planteado Warburg, que estas imágenes poseen una parte variable de "supervivencia", 43 en tanto hacen aparecer un pasado latente, pero asimismo alcanzan otros ritmos que los vinculan con su contemporaneidad: estas imágenes poseen ciertos aspectos que las afianzarían en una piedad barroca pretérita y otros que las vincularían con los ideales de una piedad íntima propios de la ilustración, de modo tal que son portadores de múltiples temporalidades.

Veamos ahora cómo estos objetos también se constituyeron en objetos portadores de significados auto-referenciales respecto del ideal que las monjas aspiraron a alcanzar al dedicar su vida al servicio divino en la clausura monástica.

\section{3.b. El desposorio místico entre la monja y Cristo}

Como hemos señalado previamente, las labores manuales gozaron de una especial importancia al interior de los monasterios porque fueron actividades capaces de conciliar una práctica activa con la contemplativa con vías al perfeccionamiento espiritual al que las monjas prometían dedicar su vida. De este modo, labores manuales y ejercicios espirituales recurrentemente fueron entrelazadas como dos caras de una moneda en construcciones discursivas que tuvieron por objeto la percepción de las monjas como mujeres virtuosas. En relación con la composición de este carácter trascendente, Fraschina ha señalado que los acontecimientos fundamentales en la vida de una monja pueden metaforizarse como una doble muerte: al siglo, mediante la profesión y físicamente, cuando se propiciaría el encuentro místico con Cristo. ${ }^{44} \mathrm{Su}$ mado a ello, Schenone ha señalado que los fana-

\footnotetext{
41 SCHENONE, Héctor. 1998, p. 106.

42 DIDI-HUBERMAN, Georges. 2008, pp. 144-147; APPADURAI, Arjun. 1986, pp. 17-87; GELL, Alfred. 2016, pp. 31-41.

${ }^{43}$ Si bien Aby Warburg ha empleado el concepto Nachleben der Antique para referir a la pervivencia de la tradición clásica, en nuestro caso parafrasearemos el término para dar cuenta de la perduración de sentidos simbólicos vinculados a la tradición cristiana y especialmente a un mensaje acorde a la devoción moderna y barroca. WARBURG, Aby. 1966.

${ }^{44}$ FRASCHINA, Alicia. 2010
} 
les del Niño Jesús formaron parte de los objetos que las monjas ingresaron al momento de su profesión a los monasterios como recuerdo de sus votos y por lo cual resulta posible suponer que los fanales serían medios eficaces para que estas mujeres enfrentasen su abandono al siglo y ejercitaran una práctica espiritual con la que pudieran visualizarse como Sponsa Christi al momento de su muerte. ${ }^{45}$ En este sentido, a continuación queremos dedicar las próximas páginas a destacar la presencia de una serie de elementos que simbólicamente contribuyeron a que los fanales fueran tanto un recordatorio de la promesa asumida por la monja al momento de su profesión como una representación de sus desposorios místicos. ${ }^{46}$

El primero de los elementos al que nos queremos referir son las flores. Su reiterada y abigarrada presencia en estos conjuntos aparece compuesta tanto en forma de arcos, borlas o guirnaldas que se adecúan al cristal y recubren al Niño Jesús. Desde una perspectiva material resulta curioso señalar que estas flores fueron elaboradas con materiales de uso cotidiano y de escaso valor tales como telas, papel, viruta, o mostacillas, así como por caracoles o conchas marinas que, a lo largo del siglo XVIII se convirtieron en un símbolo de estatus (Figs. 3 y 6) ${ }^{47}$ Acorde a su especial valoración, pareciera que las monjas habrían decidido componer motivos florales con caracoles y conchas marinas para obsequiar al niño un objeto de consabido prestigio.

Centralmente más interesante para nosotros respecto de la importancia de las flores en relación a los desposorios místicos constituye el hecho de que, como hemos mencionado previamente, las flores tuvieron un especial protagonismo en la composición de coronas de monjas novohispanas que tuvieron por objeto simbolizar la victoria conseguida por estas mujeres al momento de su profesión y muerte como símbolos del camino tomado por las monjas hacia la gloria y trascendencia. ${ }^{48}$ No obstante en nuestra región no existen datos materiales que nos permitan demostrar la antigua presencia de coronas de monjas, ramilletes o palmas de flores, consideramos que los sentidos simbólicos históricamente asignados a las flores en contexto monástico y que aquí hemos caracterizado sucintamente nos permitirían inferir que las flores presentes en los fanales habrían sido una alusión o al menos un recordatorio del desposorio místico entre la monja y Cristo. ${ }^{49}$ De este modo, y si bien estas flores gozaron asimismo de un sentido mucho más transparente, como lo fuera la veneración de la imagen, o la identificación entre el nacimiento del Niño y el período estival en latitudes sudamericanas, consideramos factible suponer que asimismo se habría establecido una relación íntima y directa entre cada monja y su fanal porque este sería símbolo de su promesa de amor hacia su divino esposo.

La hipótesis anterior cobra mayor sentido cuando notamos que algunas esculturas del Niño Jesús recostadas portan en su mano un pequeño anillo de oro, como si se tratara de un gesto de enlace matrimonial; idea que, en ciertos casos, sería reforzada por la introducción de pequeñas estatuillas en porcelana de amor galante (Fig. 5). Junto a estos objetos, las pequeñas alhajas que revestían al Niño Jesús -collares de perlas y corales, cadenitas de oro, relicarios y brazaletes- parecen amontonarse sobre estas esculturas como un recuerdo de las joyas que al momento de su profesión las monjas rechazaron en favor de una vida espiritual (Figs. 3 y 4 ).

\footnotetext{
45 DE LEÓN, Fray Luis. 1855 [1584]; VIVES, Juan Luis. 1793 [1523].

46 Sobre trabajos vinculados al tema del desposorio místico se puede consultar: MONTERO ALARCÓN, Alma. 2008, pp. 81-160; LAVRIN, Asunción. 2016, pp. 235-273; MÚJICA PINILLA, Ramón. 2005, entre otros.

47 Desde una perspectiva material es preciso señalar que a lo largo del siglo XVIII las conchas marinas se convirtieron en un objeto de lujo que integraron el comercio de curiosidades europeas y fueron adquiridas por coleccionistas, naturalistas e historiadores. Estos objetos marinos participaron de una serie de redes y prácticas asociadas a su circulación, tales como obsequios entre allegados, formación de colecciones, participación en subastas, etc. DIETZ, Bettina. 2006, pp. 363-382.

${ }^{48}$ Montero Alarcón señala que la costumbre de usar coronas floridas por las monjas al momento de su profesión y muerte procede al menos del siglo XVII. En el caso de la muerte, las coronas que las monjas lucían en sus cabezas simbolizaban la victoria por un tránsito gozoso a la gloria eterna, reservada solamente a las almas justas. Corona y palmas floridas eran merecidas por aquellas religiosas que hubieran cumplido los votos profesados: obediencia, pobreza y castidad. En los retratos de las monjas con sus coronas se puede observar una diversidad de flores recién cortadas o realizadas con diversos materiales como papel, cera, conchas marinas, telas o cuentas de vidrio. A estos arreglos se fueron incorporando sucesivos elementos como pájaros y mariposas o pequeñas esculturas en cera con imágenes de santos o del Niño Jesús. MONTERO ALARCóN, Alma. 2008, pp. 179-287.

49 Baste para ello recordar cómo la muerte incorrupta era también conocida como una "muerte en olor de santidad" por el cual se aludía al olor o la presencia milagrosa de flores, tal como sucedió con Santa Rosa de Lima. MÚJICA PINILLA, Ramón. 2005. Asimismo, los fanales recurrentemente presentan flores dotadas de múltiples sentidos simbólicos, tales como las rosas que aluden a la muerte en santidad, lirios que refieren al carácter virginal de María, entre otros.
} 
En este sentido, y acorde a las apropiaciones de las monjas para componer estos fanales, consideramos que las pequeñas ovejas compuestas por perlas que forman parte de un fanal en el que se representaba al Niño Jesús recostado procedente del Monasterio de Santa Catalina de Córdoba pudieron ser a la vez símbolo del rechazo a los bienes materiales y del desposorio místico asumido por la monja. ${ }^{50} \mathrm{Co}$ mo ya es sabido, las monjas se consideraban a sí mismas como el rebaño de Jesús, o mejor dicho sus ovejas predilectas. ${ }^{51}$ Pareciera que, en el caso de estas ovejas de perlas, la misma monja habría querido componer su imagen como parte del rebaño que sigue los pasos del divino esposo tras el rechazo a los bienes del siglo. Para ello, la monja parecería haber decidido refuncionalizar las perlas con el objeto de componer una imagen que represente ahora su riqueza espiritual y su sincero enlace con Cristo. Ahora bien, si recordamos que al interior del monasterio la posesión de bienes materiales era un signo de distinción, no sería aventurado suponer que las monjas hubieran hecho un empleo consciente de estos materiales acorde a sus implicancias simbólicas para componer el más bello de los fanales y denotar la distinción social de su antigua vida en el siglo.

\section{Conclusión}

A lo largo de estas páginas hemos propuesto un análisis visual para comprender el sentido simbólico adquirido por una serie de fanales del Niño Jesús elaborados a comienzos del siglo XIX por las monjas de los monasterios de Santa Catalina y San José de Córdoba en el marco de labores manuales. Allí, ciertas prácticas cotidianas fueron revestidas de un carácter virtuoso para componer el carácter ejemplar de las monjas. En este juego de relaciones entre virtudes femeninas y apropiación de la iconografía cristiana, ciertos materiales de bajo costo se combinaron con otros de especial prestigio para componer una imagen sagrada. Así, estos fanales del Niño Jesús no solo fueron valorados en tanto objetos devocionales sino que también habrían resultado un medio propicio pa- ra exhibir el compromiso asumido por estas mujeres con su Divino Esposo.

El carácter polisémico de los fanales del Niño Jesús que hemos identificado a partir de un estudio minucioso de las prácticas que les dieron origen desde una perspectiva histórico-cultural junto con el análisis de las características materiales y el estudio iconográfico aquí propuesto nos ha permitido reconocer que estos objetos resultaron eficaces no solo en las vísperas de la Navidad, sino que su eficacia resultó cotidiana e ineludible. En este sentido, la presencia de elementos que insistentemente recordaran el carácter encarnado y sacrificial de Cristo sin duda cobraron un sentido de especial relevancia durante el Ciclo de la Pasión, pero también este mensaje se constituyó al interior de la clausura como un ejemplo moral que las monjas debían diariamente emular.

Para ello, la presencia de numerosos elementos que recordaran a las monjas su compromiso asumido con Cristo, tales como los anillos del enlace, las flores como metáfora del vergel, o la presencia de numerosos animales que remiten al temperamento ideal de las monjas, conforman una yuxtaposición de sentidos simbólicos que hasta el momento no habían sido analizados en profundidad. Estos elementos se conjugaron para componer sucesivas resignificaciones en el marco de una práctica espiritual que se materializó en un saber hacer a través de la labor de manos a la vez que tejió significados relativos al carácter virtuoso de las monjas mediante su instrucción espiritual. De este modo, virtud, práctica y ejercicio cotidiano parecieran haber confluido en un mismo objeto que no tardaría en ser percibido y valorado por los agentes laicos vinculados a estos monasterios. Como afirma De Certeau tras la influencia de Teresa de Ávila estas actividades técnicas -como el bordado o el hilado- se convirtieron en el lenguaje de la búsqueda espiritual. ${ }^{52}$

El recorrido emprendido a lo largo de este artículo tuvo por objeto dar cuenta de una metodología de trabajo que, frente a la carencia de fuentes docu-

\footnotetext{
${ }^{50}$ Las ovejas son reproducidas en BARBIERI, Sergio. 2006, p. 137. Aljofarar era el término que en el siglo XVII se empleaba para denominar la acción de cubrir o adornar con perlas o aljófar alguna cosa para que pareciera formada de perlas. VARGAS LUGO, Elisa; CURIEL, Gustavo. 1991, p. 274.

51 Una obra elocuente sobre este tema es el lienzo realizado por Juan Rodríguez Juárez titulado El divino pastor, y especialmente realizada para un monasterio carmelita novohispano. La pintura tiene una directa alusión a las ars moriendi y los modelos de virtud y perfección religiosa que debió desarrollarse en la clausura. Asimismo, otra imagen que tuvo por objeto ser contemplada por las monjas en contexto conventual es la ya conocida obra de Miguel Cabrera El Divino esposo recostado entre flores en un jardín místico. Estos jardines eran alegorías visuales que refirieron al estado espiritual de la vida monástica y cuyo objetivo consistió en conducir a sus espectadoras a la perfección virtuosa. KATZEW, Ilona ed. 2017, pp. 400-404.

52 DE CERTEAU, Michel. 2006, p. 57.
} 
mentales pormenorizadas que refieran a los fanales del Niño Jesús, entrecruce ciertos aspectos visuales y culturales para comprender los diversos usos y funciones de estos objetos durante las primeras décadas del siglo XIX. Sin ánimos de considerar que la perspectiva de análisis aquí propuesta sea un planteo consumado, el espíritu de este trabajo tuvo por meta presentar la complejidad del estudio de este tipo de obras y abogar, si se nos permite, por la expansión del objeto de estudio de la historia del arte. Para ello, este trabajo se ha nutrido de las perspectivas teórico-metodológicas de la historia cultural, la antropología de la imagen y la iconología a la vez que atendió a ciertas dimensiones materiales de dichos objetos. En este sentido, las prácticas piadosas, las lecturas espirituales, las labores manuales y los gestos de la devoción en interrelación con los sentidos simbólicos de las imágenes que se incluyen en los fanales del Niño Jesús y su heterogénea materialidad constituyen huellas e indicios que para comprender algunas de las formas que adoptó la manifestación de la espiritualidad y la construcción de la virtud femenina al interior de los monasterios.

\section{Fuentes textuales}

DE LEÓN, Fray Luis. La perfecta casada. Madrid: Rivadeneyra, 1855 [1584].

FIDANZA, Juan de (san Buenaventura). Meditaciones de la vida de Cristo. Madrid: s/d, 1893 [s. XIII].

FLORENCIA, Francisco de. La milagrosa invención de un tesoro escondido. Nueva España, Doña María Venavides, viuda de Juan de Ribera, 1685.

NúÑEZ, Antonio, S.J., Distribución de las obras ordinarias y extraordinarias del día, para hacerlas perfectamente, conforme al estado de las señoras religiosa. Instruidas con doce máximas substanciales para la vida regular y espiritual que deben seguir. Publicadas por el convento de la Encarnación. México: viuda de Miguel Ribera Calderón, 1712.

VEGA CARPIO, D. Frey Lope Félix de. Colección de las obras sueltas assi en prosa como en verso, tomo III. Madrid: Imprenta de don Antonio de Sancha, 1776.

VIVES, Juan Luis. Instrucción de la Muger Cristiana. Madrid: Imprenta de Don Benito Cano, 1793 [1523].

La Regla y Constituciones de las monjas de la Orden de Santo Domingo. Santiago de Chile: Imprenta de la Opinión, 1863.

Regla de la Gloriosa Santa Clara con las Constituciones de las Monjas Capuchinas del Santísimo Sacramento de Roma, reconocidas y reformadas por el Padre General de los Capuchinos. Buenos Aires: Tipografía del colegio Pio IX, 1904.

Regla y Testamento de Santa Clara. Constituciones de las Monjas Clarisas Capuchinas. Roma: Curia General de los Hermanos Menores Capuchinos, 1904.

\section{Bibliografía crítica}

APPADURAI, Arjun ed., The social life of things. Commodities in cultural perspective. Cambridge: University Press, 1986.
ARBETETA MIRA, Letizia. Navidad Oculta II. Los Niños Jesús de las Clausuras Toledanas. Toledo, Antonio Pareja Editor, 2002.

BÁEZ, Rolando; VARGAS, Emilio. Fue nuestro gozo cumplido. Fanales de la colección del Museo de la Merced. Santiago de Chile: Museo de la Merced, 2015.

BARBIERI, Sergio. Patrimonio artístico nacional. Inventario de bienes muebles. Iglesia y Monasterio de Santa Catalina de Siena de Córdoba. Buenos Aires: Academia Nacional de Bellas Artes, 2006.

BROWN, Bill. "Thing theory". Critical Inquiry, 2001, n²8, 1, pp. 1-22.

CALABRESE, Omar. "Detalle y fragmento" en La era neobarroca. Madrid: Cátedra, 1999.

COHEN IMACH, Victoria. "Decir verdad. Pesquisa secreta en un convento femenino (siglo XVIII)". Acta literaria, 2003, n 28, pp. 19-32.

DE CERTEAU, Michel. La debilidad de creer. Buenos Aires: Katz, 2006.

DIDI-HUBERMAN, Georges. "Pour une anthropologie des singularités formelles. Remarques sur I invention warburguienne". Genéses. Sciencies sociales et histoire, 1996, n²4, pp. 145-163.

DIDI-HUBERMAN, Georges. Ante el tiempo. Historia del arte y anacronismo de las imágenes. Buenos Aires: Adriana Hidalgo, 2008.

DIETZ, Bettina. "Mobile objects: the space of shells in eighteenth- century France". The British Journal for the History of Science, 2006, $n^{\circ} 39,3, \mathrm{pp} .363-382$.

FOGELMAN, Patricia. "La religiosidad en el museo" en Lo sagrado en el museo. XV Cátedra de Historia Ernesto Restrepo Tirado. Bogotá: Museo Nacional de Colombia, 2012, pp. 5-35.

FRASCHINA, Alicia. "Reformas en los conventos de monjas de Hispanoamérica 1750-1865: Cambios y continuidades". Hispania Sacra, 2008, n LX, 122, pp. 445-466.

FRASCHINA, Alicia. Mujeres consagradas en Buenos Aires colonial. Buenos Aires: Prohistoria, 2010.

FRICKE, Beata "Matter and meaning of Mother-of-pearl: The origins of Allegory in the spheres of things". Gesta, 2012, n 51, 1, pp. 35-53.

GARCÍA SANZ, Ana. El Niño Jesús en el Monasterio de las Descalzas Reales de Madrid. Madrid, Prosegur y Patrimonio Nacional, 2010.

GELL, Alfred. Arte y agencia. Una teoría antropológica. Buenos Aires: SB, 2016.

KATZEW, Ilona ed. Pintado en México 1700-1790. MéxiCo: LACMA, Banamex, 2017.

LAVRIN, Asunción. Las esposas de Cristo. La vida conventual en la Nueva España. México: Fondo de Cultura Económica, 2016.

MARIN, Louis. "Poder, representación, imagen", Prismas, revista de historia intellectual, 2009, $\mathrm{n}^{\circ} 13$, pp. 135-153.

MONTERO ALARCón, Alma. Monjas coronadas. Profesión y muerte en Hispanoamérica virreinal. México: INAH, CONACULTA, 2008.

MÚJICA PINILLA, Ramón. Rosa limensis. Mística, política e iconografía en torno a la patrona de América. Lima: Fondo de Cultura Económica, 2005.

NIEVA OCAMPO, Guillermo. "El Obispo, el Síndico y la Priora: el reformismo borbónico y el monasterio de Santa Catalina de Córdoba del Tucumán (1780-1810)". Archivo dominicano, 2011, $\mathrm{n}^{\circ}$ XXXII, pp. 53-91.

PEÑA MARTíN, Ángel. "El peregrino del cielo: la devoción al Niño Jesús peregrino en las clausuras femeninas". En: La clausura femenina en el Mundo Hispáni- 
co: una fidelidad secular. San Lorenzo del Escorial, Estudios Superiores del Escorial, 2011, vol. I, pp. 31-48.

PEÑA MARTíN, Ángel. Arte, imagen y monasterios en el Quito Virreinal, siglos XVI-XVIII. El ciclo litúrgico de Navidad, Tesis doctoral en historia y teoría del arte. Madrid, Universidad Autónoma de Madrid, 2017.

RAMOS SOSA, Rafael (dir. y coord.). Actas del Coloquio Internacional El Niño Jesús y la Infancia en las Artes Plásticas, siglos XV al XVII. IV centenario del Niño Jesús del Sagrario, 1606-2006. Sevilla, Archicofradía del Santísimo Sacramento del Sagrario de la Catedral de Sevilla, 2010.

RÉAU, Louis. Iconografía del arte cristiano. Barcelona: Serbal, 2000.

RIEGL, Alois. El arte industrial tardorromano. Madrid: Visor, 1992 [1903].

RODRÍGUEZ NÓBREGA, Janeth. "El arte colonial y la mujer: la iconografía religiosa como paradigma de la conducta", Tierra Firme, 1999, n67, 17, pp. 371-386.

SANFUENTES, Olaya. "Agricultura y cultura en el convento de monjas. Una especial devoción al Niño Jesús en el siglo XIX", Estudio Avanzados, 2011, n 16, pp. 161-180.

SCHENKE, Josefina. "Objetos devocionales en una ciudad virreinal periférica (Santiago de Chile, 15981610; 1692-1710)", Revista de Historia Social y de las Mentalidades, 2010, n 14, 2, pp. 137-172.

SCHENONE, Héctor. "La imagen del Niño Jesús en Hispanoamérica", Saber Vivir, VIII, 95 (marzo-abril 1951): 32-37.
SCHENONE, Héctor. Iconografía del arte colonial. Jesucristo. Buenos Aires: Fundación Tarea, 1998.

SCHENONE, Héctor. "Apuntes para una hipótesis sobre la pintura colonial sudamericana". Tarea, 2014, n 1, pp. 91-99.

SCOCCHERA, Vanina. "Ollando mundo y riquezas... Dádivas y obsequios de objetos devocionales en el Monasterio de Santa Catalina de Sena - Córdoba del Tucumán, siglo XVIII". Avances, 2013-2014, n² 23, pp. 395-409.

SCOCCHERA, Vanina. Objetos de devoción y culto: prácticas piadosas, intercambios y distinción entre agentes laicos y religiosos en las diócesis de Buenos Aires y Córdoba (mediados del siglo XVIII, primer cuarto siglo XIX). Tesis doctoral de Teoría e Historia de las Artes, Facultad de Filosofía y Letras, Universidad de Buenos Aires (inédita), 2019.

SEMPER, Gottfried. Style in the technical and tectonic arts, or, practical aesthetics, intr. de Harrys Francis Mallgrave. Los Ángeles: Getty Publications, 2004.

SIRACUSANO, Gabriela. El poder de los colores. De lo material a lo simbólico en las prácticas culturales andinas. Siglos XVI-XVIII. Buenos Aires: FCE, 2005.

VARGAS LUGO, Elisa; CURIEL, Gustavo. Juan Correa F. Su vida y su obra. Cuerpo de documentos, tomo 3. México: UNAM, 1991

WARBURG, Aby. La Rinascita del Paganesimo Antico. Contributi alla storia della cultura. Florencia: La Nuova Italia, 1966. 